\title{
EFFECT OF FLOW STEERING ANGLE TOWARD THE HYDROKINETIC TURBINE PERFORMANCE
}

\author{
Rudy Soenoko \\ Department of Mechanical Engineering \\ Brawijaya University \\ $1 \mathrm{Jl}$. Veteran, Malang, Indonesia, 65145 \\ rudysoen@ub.ac.id \\ Hastono Wijaya \\ Department of Mechanical Engineering \\ Brawijaya University \\ $1 \mathrm{Jl}$. Veteran, Malang, Indonesia, 65145 \\ whastono@ub.ac.id
}

\begin{abstract}
The kinetic turbine is one of the solutions for use in low-speed river flows ranging from $0.01-2.8 \mathrm{~m} / \mathrm{s}$. This kinetic turbine is used as a conversion equipment to convert the water kinetic energy into an electrical energy. The working principle of a kinetic turbine is utilizing and relies on the water kinetic energy. Water flowing into the turbine area will produce a momentum on the turbine blades. This momentum change would then push the turbine blades and finally spin the turbine runner. The aim of research is thedetermination of the effect of water flow steering angle $(\alpha)$ and water flow rate variation in the kinetic turbine performance. This research uses vertical axis kinetic turbines with eight curve blade attached to the turbine runner. The variables used are two values of water flow steering angle, namely $25^{\circ}$ and $35^{\circ}$. The water flow rate variation of $30 \mathrm{~m}^{3} / \mathrm{h}$, $35 \mathrm{~m}^{3} / \mathrm{h}, 40 \mathrm{~m}^{3} / \mathrm{h}$ and $45 \mathrm{~m}^{3} / \mathrm{h}$. The method used in this study uses a real experimental method. These two variations would then compare with the result of a hydrokinetic turbine performance done on the previous research.

The results show that the water flow steering angle $\alpha$ affected the kinetic turbine performance (power, efficiency and torque). From these several water flow steering angle and water flow rate variations, the turbine performance with a $35^{\circ}$ water flow steering angle get the highest performance compared with the use of $25^{\circ}$ and $14^{\circ}$ water flow steering angle. The greater the flow angle and the greater the water flow rate, the greater the torque, power and efficiency. The highest turbine power produced, $\mathrm{P}=17.5 \mathrm{~W}$, occurs on the $35^{\circ}$ water steering angle, and on a $\mathrm{Q}=45 \mathrm{~m}^{3} / \mathrm{h}$ water flow rate and on a $80 \mathrm{rpm}$ turbine rotation. While the highest turbine efficiency, $\eta=27 \%$, occurred on the $\mathrm{Q}=30 \mathrm{~m}^{3} / \mathrm{h}$ water flow rate, on a $60 \mathrm{rpm}$ turbine rotation and on a water flow steering angle $\alpha=35^{\circ}$. The highest turbine torque, $3.1 \mathrm{Nm}$, occurs at $\mathrm{Q}=45 \mathrm{~m} 3 / \mathrm{h}$ water flow rate at a maximum turbine braking and on a water steering angle $\alpha=35^{\circ}$.
\end{abstract}

Keywords: kinetic turbine, curve blade, experimental, torque, efficiency, power, steering angle.

\section{Introduction}

The World Climate Change Summit or UNFCCC COP21 held in Paris aims to keep the global temperature rise below $2{ }^{\circ} \mathrm{C}$, compared to temperatures before the Industrial Revolution, and encourage further efforts to increase the temperature to no more than $1.5^{\circ} \mathrm{C}$. At the conference Indonesia was committed to reducing its greenhouse gas (GHG) emissions in 2020 by $26 \%$ with its own efforts, and up to $41 \%$ with international assistance set forth in the NDC (Nationally Determined Contribution). The government has issued various policies on "energy transition" with the main issue of increasing the use of low-carbon energy technology or often called clean energy technology.

However, how much the impact of this policy on GHG emission reduction targets needs to be studied in depth. Furthermore, what types of clean technology are feasible to apply in Indonesia also need to be analyzed.

Besides emissions, Indonesia's huge dependence on oil and coal deserves attention. The limitation of fossil energy resources makes the transition to new and renewable energy is a must, not just an option. Non-conventional gases such as shale gas and CBM (Coal Bed Methane) are examples of new energy that have the potential to strengthen the national energy diversification and resilience. 
New and renewable energy (NRE) is very important to realize energy security in the future. Moreover, Indonesia has the potential of NRE of more than $441 \mathrm{GW}$. So far, only $8.89 \mathrm{GW}$ has been realized.

Of the total potential of water energy, its utilization on a large scale hydro power is still 3,783 MW, and small scale is $220 \mathrm{MW}$. Micro Hydro Power Plant (MHPP) is a small-scale power plant whose output power is below the hydro power and is a power plant that utilizes low speed water energy [1]. One of the small-scale water energy sources is the river flow that has a low speed ranging from 0.01 to $2.8 \mathrm{~m} / \mathrm{s}$.

One of the uses of low speed water energy is implementing a kinetic turbine. This kinetic turbine utilizes the water flow kinetic energy in the form of a river water speed flow. The water flow directly hits the turbine blade and causes the turbine runner to spin. The water kinetic energy was converted to a turbine mechanical energy driving a generator to produce electricity [2].

Microhydro is a renewable energy. From several studies, information was obtained about the potential of hydro along the Brantas River [3]. This water potential is in the form of mechanical energy or electrical energy. The energy conversion starts from the water kinetic energy change into a mechanical energy in the form of turbine rotation.

In its development, kinetic turbines have two types, which are the horizontal shaft kinetic turbine and the vertical shaft kinetic turbine [4]. While the kinetic turbines used in this study are a curved bladed vertical shaft kinetic turbine. The shaft is placed vertically so that the generator installation is easier and the entire blade gets a boost from the flow of water [5].

The use of curve shaped blades in this study is because the mass distribution of water through a bouncing curve blade spread in all directions. This flow will increase the turbine tangential force, so that turbine torque increases and results a turbine performance increase [6]. Therefore, the input angle formed by the absolute speed and the tangential speed is very important to be noted.

Based on this angle, the initial formation of the turbine blade curve is carried out. This curved angle will increase the mass of water flow when the water hits the turbine blade. The turbine torque increases and of course the kinetic turbine performance increase [7].

The aim of research is the determination of the effect of flow steering angle variations on a kinetic turbine performance. The results of this research can help the community to meet electrical energy needs, and as a source of reference for other researchers in designing and developing the curved blade kinetic turbine.

The research team of the mechanical engineering department of the Brawijaya University decided to observe the simple turbines (micro hydro) that utilize secondary, tertiary and quarter channels along the Brantas River. One of the places chosen for this initial study has a specification of $3,1 \mathrm{~m}^{3} / \mathrm{s}$ water flow rate, a $125 \mathrm{~cm}$ channel width, a Manning roughness coefficients $\mathrm{n}=0,01$ and a $0,65 \mathrm{~m}$ channel depth. This location has the basic specification for the kinetic turbine project.

In order for this research to be carried out as optimally as possible, the research was conducted in the laboratory of Fluid Mechanic Brawijaya University. The consequence of this decision must be made under a laboratory scale. This means that the research is a sort of model test that adheres to the similarity method.

\section{Literature review and problem statement}

Hydrokinetic turbine is a simple turbine that utilizes water flow kinetic energy. This turbine is easy to make, the manufacturing costs are not expensive, the erection is easy, the operation is easy and the maintenance is not difficult. The disadvantage of this type of turbine is its low performance. This hydrokinetic turbine is the development of a water mill.

Many kinetic turbine problems are addressed directly in the field based on the water flow behavior, but there is still no problem-solving research that is officially published internationally. Users are not interested in developing it, because it is assumed that the turbine is simple, easy to manufacture and low efficiency is not a problem. Many factors are thought to be the cause of this low performance, both related to the neatness of the construction and the behavior of the water flow.

There is not much research on hydrokinetic turbine published in international journals. There are many studies about hydrokinetic turbines, but it is published in a national level journal. 
A study of hydrokinetic turbine [8] is introducing magnetic a coupling to improve turbine efficiency. This study attempts to solve low turbine efficiency by minimizing mechanical losses. Another study about a dynamic hydrokinetic [9], discuss about how to increase a hydrokinetic turbine performance. It is necessary to develop a method that is able to increase the performance of hydroelectric power plants. The focus of this study is the mechanical energy lost. So this research focuses on shaft coupling by applying speed multipliers.

There are other studies that suggest a Darrieus hydrokinetic turbine [10]. Darrieus turbine is generally used for wind turbines, where the fluid is an incompressible fluid. This type of hydrokinetic turbine is believed to increase the hydrokinetic turbine performance.

Another study, conducted a research on hydrokinetic turbine by combining the turbine blade number and the flow steering blade angle [11]. This research leads to optimize the water flow direction passing through the hydrokinetic turbine.

An observation of a multilevel hydrokinetic turbine called Vertical Axis Hydrokinetic Turbine - Cascaded Straight-Blade (VAHT-SBC) was studied with three blade number variations. This type of turbine was tested experimentally in the laboratory and tested numerically [12]. The purpose of this study is to examine which VAHT-SBC model has the best performance.

A study, about the hydrokinetic turbine, conducted a CFD analysis. This analysis is trying to compare several variations of a three positions water inlet into the turbine to get the best inlet water flow. The best water inflow would produce a high hydrokinetic turbine performance [13]. This study discusses about the behavior of water flow entering the hydrokinetic turbine.

Furthermore an article discusses a computer code algorithm to calculate the ducted axial-flow hydrokinetic turbine characteristic [14]. The main purpose of this study discussion is detection of vortices and cavitation that occur in hydrokinetic turbine.

Another paper review works by involving small axial hydrokinetic turbines, specifically generating electricity for remote communities outside the national grid network. The review suggests improvements to overcome major problems. However, some deployments have experienced major problems with garbage attached to the turbine, which has resulted in disrupted operations. Again, this is related to the flow of water entering the turbine [15].

Other studies discuss hydrokinetic turbine with a hinged blade. Installing this hinge is so that the blade can move towards the outside when the back side blade gets a water pressure. Hinged blade construction will reduce the negative forces occurrence. Negative forces will produce a negative momentum, which of course will reduce the hydrokinetic turbine performance [16].

From several studies that have already been mentioned, there is a lot of research on improving the performance of a hydrokinetic turbine. The research that will be conducted is to get the best performance hydrokinetic turbines. All topics discuss design optimization, which actually talks about the water flow. One thing that has not been observed in depth is how the behavior of water flows in the turbine area. How water flows push the blade. Does the speed of the water flow really produce a force on the blade, which is very much related to the turbine performance? A study about a bowl bladed hydrokinetic turbine [17] shows that water flow only pushes on one blade.

Of all the reviews mentioned above, it is necessary for an initial study to design a hydrokinetic turbine that is appropriate for a location that has a certain specification.

Therefore, it was decided to conduct a laboratory research for a turbine, which will be installed in a certain area.

\section{The aim and objectives of research}

This research is determining the effect of the flow steering angle of an eight curved bladed kinetic turbine, as a source of designing and developing kinetic turbines. This study is expected to help the community in using alternative energy prime mover, especially in rural areas.

The aim of this research is the investigation of the kinetic turbine performance under a different flow steering angle.

To achieve this goal, the following tasks are set:

- Find out how the flow steering angle influence the kinetic turbine performance. The turbine performance intended are the turbine power, turbine torque and turbine efficiency. 
- Investigate, what is the best flow steering angle to get the optimal turbine performance (turbine power, turbine torque and turbine efficiency).

\section{Material and Methods on the flow steering angle that affect the hydrokinetic turbine per- formance}

\section{1. Kinetic turbine}

Kinetic turbine is a simple prime mover to generate electricity. This kind of turbine is used in rural areas. It is expected that this turbine could be easily operated. A lot of research was conducted to raise the turbine performance.

As mentioned above that turbine, which will be observed in the study, has been tested for its performance in the Brawijaya University fluid mechanics laboratory. In this test, what was done was to record all the performance variables of the turbine. The parameters recorded are water flow rate, turbine rotation (RPM), turbine torque and water velocity. This turbine has a drum diameter of $120 \mathrm{~mm}$. The turbine blades have a specification of $110 \mathrm{~mm}$ chord length and $110 \mathrm{~mm}$ blade height. The number of blades is 8 pieces and all blades connect with a drum with a hinge. Each blade can open and close freely around the hinge pin before positioned perpendicular to the drum and stopping at a stop. The aim of using this hinged system is to prevent the water back flow to reduce the turbine power [6, 7]. These whole turbine test installation dimensions were taken based on the geometrical similarities.

It is quite clear that each blade will get two dynamic processes in full rotation, namely the opening and closing process. But it is difficult to determine accurately when these two processes are triggered or resolved by a certain water flow rate only with theoretical analysis.

This turbine is tested with several variations of water flow rates, namely $35 \mathrm{~m} / \mathrm{h}, 40 \mathrm{~m}^{3} / \mathrm{h}$, $45 \mathrm{~m}^{3} / \mathrm{h}$ and $50 \mathrm{~m}^{3} / \mathrm{h}$. These water flow rate values were chosen to adjust with the duct available in the laboratory. The other parameters are the turbine breaking (similar to a prony break) to measure the turbine torque. From the turbine torque, the turbine horse power could be calculated.

\section{2. Kinetic Turbine Power}

The power of a kinetic turbine is determined by the amount of power produced by the flow. The kinetic turbine power is calculated using the equation below:

$$
\mathrm{P}_{\mathrm{a}}=\frac{1}{2} \cdot \rho \cdot \mathrm{Q} \cdot \mathrm{v}^{2}
$$

Using the continuity equation $\mathrm{Q}=\mathrm{A} \cdot \mathrm{v}$ so that the equation becomes:

$$
\mathrm{P}_{\mathrm{a}}=\frac{1}{2} \cdot \rho \cdot \mathrm{A} \cdot \mathrm{v}^{3}
$$

with $\mathrm{P}_{\mathrm{a}}$ - Water power $(\mathrm{W}) ; \rho-$ specific weight $\left(\mathrm{kg} / \mathrm{m}^{3}\right) ; \mathrm{A}-$ cross sectional area $\left(\mathrm{m}^{2}\right) ; \mathrm{v}-$ water flow velocity $(\mathrm{m} / \mathrm{s})$.

The equation below is used to determine the turbine break horse power (Fig. 1):

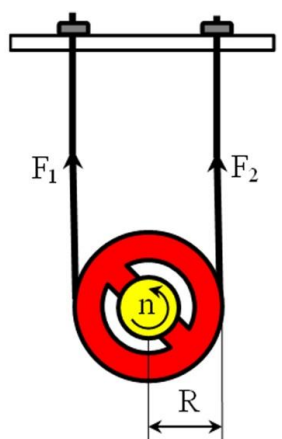

Fig. 1. Torque measurement 


$$
\mathrm{P}_{\mathrm{t}}=\mathrm{T} \cdot \omega
$$

where $\mathrm{T}=\mathrm{F}_{\mathrm{t}}$. $\mathrm{R}$ and $\omega=2 \cdot \pi \cdot \mathrm{n} / 60$.

With $\mathrm{P}_{\mathrm{t}}-$ Turbine power $(\mathrm{W}) ; \mathrm{T}-$ Torque $(\mathrm{Nm}) ; \omega-$ angular velocity $(\mathrm{Rad} / \mathrm{s}) ; \mathrm{R}-\mathrm{Pulley}$ radius $(\mathrm{m}) ; \mathrm{n}$ - turbine rotation (rpm); $\mathrm{F}_{\mathrm{t}}-$ tangential force $(\mathrm{N}) ; \mathrm{F}_{\mathrm{t}}=\mathrm{F}_{1}-\mathrm{F}_{2}$.

The kinetic turbine efficiency is determined from the ratio between the input water power by the power turbine power (Fig. 2)

$$
\eta=\frac{P_{t}}{P_{a}}
$$

where $\mathrm{P}_{\mathrm{t}}$ - turbine power $(\mathrm{W}) ; \mathrm{P}_{\mathrm{a}}-$ water power $(\mathrm{W})$.

$$
\mathrm{Q}=\mathrm{VxA}
$$

where $\mathrm{Q}$ - water flow rate $\left(\mathrm{m}^{3} / \mathrm{h}\right) ; \mathrm{V}$ - water velocity $(\mathrm{m} / \mathrm{s}) ; \mathrm{A}$ - cross-sectional area $(\mathrm{m})$.

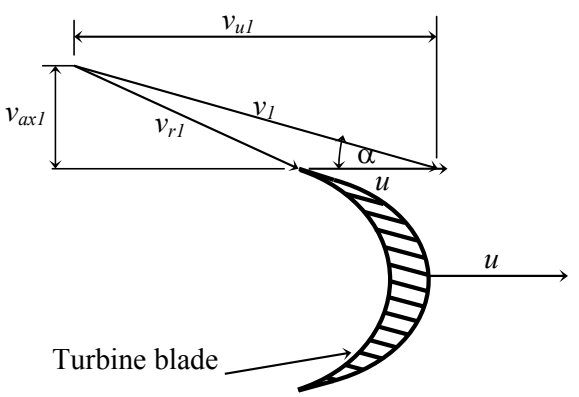

Fig. 2. Velocity triangle

$$
\mathrm{V}_{\mathrm{r} 1}=\sqrt{\left(\mathrm{v}^{2}+\mathrm{u}^{2}\right)-2(\mathrm{v} \cdot \mathrm{u} \cdot \cos \alpha)},
$$

where $\mathrm{v}$ - fluid absolute velocity; $\mathrm{u}$ - Blade linear velocity; $\mathrm{v}_{\mathrm{r}}$ - fluid relative velocity after contact with blade; $v_{w}$ - Tangential component of v, called Whirl Velocity; $v_{f}-$ Flow velocity; $\alpha$ - angle made by $\mathrm{v}$ with the plane of the machine.

From the velocity triangle it can be seen that the larger the water velocity $v_{1}$ enters the turbine blade, the greater the u blade speed.

\section{3. Experimental installation}

In this study, the turbine was submerged in a research duct. The duct size was limited by the duct cross sectional area. Convergent parts are installed upstream to accelerate the water flow rate entering the turbine. The turbine blades are the standard curved blade (Fig. 3), it has the same distance around the drum.

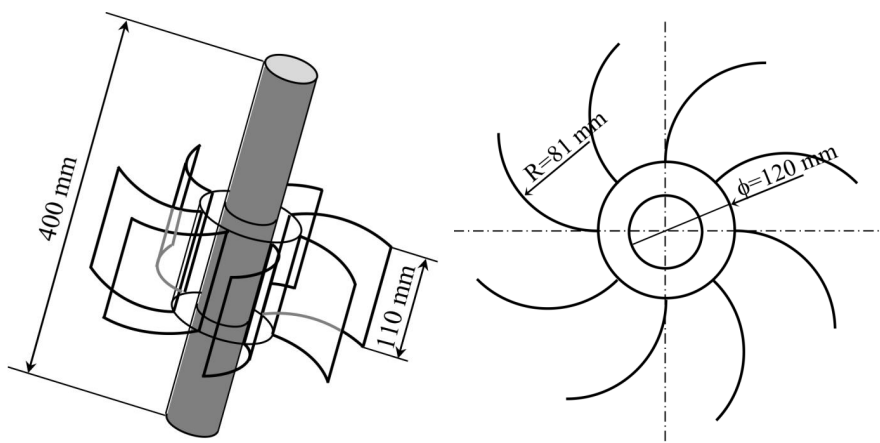

Fig. 3. Turbine Dimension 
At Fig. 4, it is shown the hydrokinetic turbine attached in the research water duct. $\alpha$ on the water duct is the water flow steering angle.

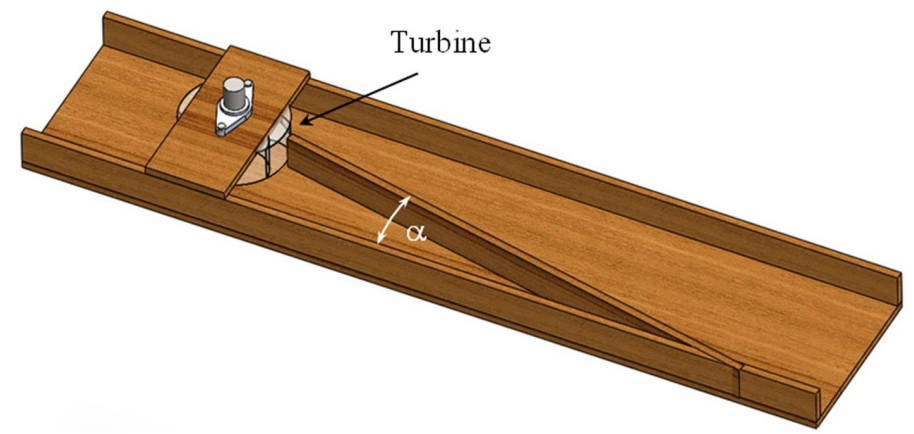

Fig. 4. Experimental Duct Installation ( $\alpha=$ flow steering angle)

During the observation, a water flow regulator (Fig. 5) is used to control the water flow rate, especially for the water flow rate variation regulation.

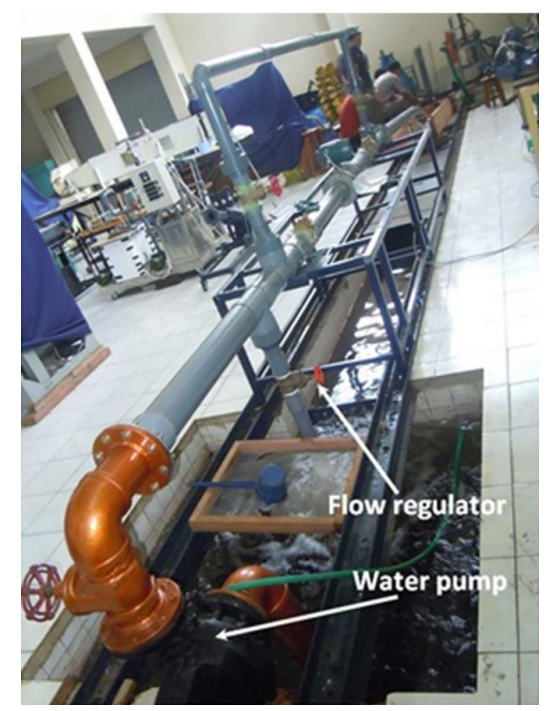

Fig. 5. Water Flow Rate Regulator

The turbine rotation (rpm) was also measured for every turbine parameter variation (Fig. 6).

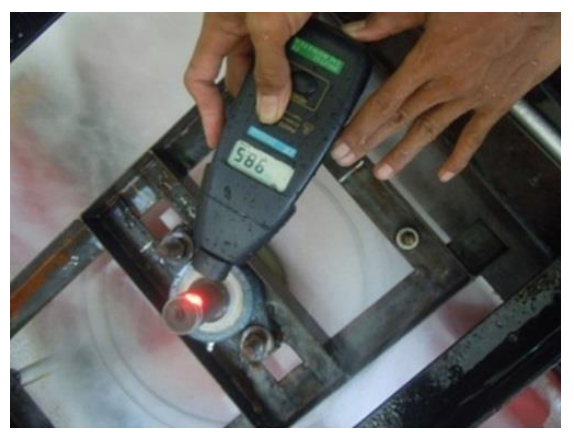

Fig. 6. rpm measurement

This turbine has been tested for its performance, under a number of conditions, variations in parameters for obtaining turbine performance. 


\section{Result and discussions on the flow steering angle that affect the hydrokinetic turbine per- formance}

As mentioned above, the laboratory model is a similarity calculation result for a small power plant construction site. From the similarity results, the water flow rate value has been obtained, which is between $30 \mathrm{~m}^{3} / \mathrm{h}$ and $45 \mathrm{~m}^{3} / \mathrm{h}$. So the water flow rate variation chosen in this study is $30 \mathrm{~m}^{3} / \mathrm{h}, 35 \mathrm{~m}^{3} / \mathrm{h}, 40 \mathrm{~m}^{3} / \mathrm{h}$ and $45 \mathrm{~m}^{3} / \mathrm{h}$. While for the turbine torque result values, turbine rotation values selected are $90 \mathrm{rpm}, 70 \mathrm{rpm}, 50 \mathrm{rpm}, 30 \mathrm{rpm}$ and a maximum braking turbine rotation which is equal to $0 \mathrm{rpm}$. In this first observation, the chosen angle of steering angle is $25^{\circ}$. The results of laboratory tests for observing turbines with 8 blades and steering angle $\alpha=25^{\circ}$ can be seen in Table 1.

Table 1

Kinetic Turbine Test Results $\left(\alpha=25^{\circ}\right)$

\begin{tabular}{|c|c|c|c|c|c|c|c|}
\hline $\mathbf{Q} \mathbf{m}^{3} / \mathbf{h}$ & n (rpm) & $\Delta \mathbf{F}(\mathbf{N})$ & $\mathbf{V}(\mathrm{m} / \mathrm{s})$ & $\mathrm{T}(\mathrm{Nm})$ & Water Power & Turbine Power & Eff \\
\hline 30 & 90 & 4,9 & 2,6 & 0,686 & 32,8 & 6,46 & 19,7 \\
\hline 30 & 70 & 8,5 & 2,6 & 1,19 & 32,8 & 8,72 & 26,58 \\
\hline 30 & 50 & 9,7 & 2,6 & 1,358 & 32,8 & 7,11 & 21,67 \\
\hline 30 & 30 & 10,6 & 2,6 & 1,484 & 32,8 & 4,66 & 14,21 \\
\hline 30 & 0 & 13,4 & 2,6 & 1,876 & 32,8 & 0 & 0 \\
\hline 35 & 90 & 7,5 & 2,86 & 0,784 & 45,36 & 7,39 & 16,28 \\
\hline 35 & 70 & 11,8 & 2,86 & 1,106 & 45,36 & 8,10 & 17,86 \\
\hline 35 & 50 & 15,9 & 2,86 & 1,526 & 45,36 & 7,99 & 17,61 \\
\hline 35 & 30 & 18,7 & 2,86 & 1,82 & 45,36 & 5,72 & 12,6 \\
\hline 35 & 0 & 22,4 & 2,86 & 1,918 & 45,36 & 0 & 0 \\
\hline 40 & 90 & 7,2 & 3,25 & 1,008 & 65,896 & 9,49 & 14,41 \\
\hline 40 & 70 & 9,6 & 3,25 & 1,344 & 65,896 & 9,85 & 14,94 \\
\hline 40 & 50 & 12,6 & 3,25 & 1,764 & 65,896 & 9,23 & 14,1 \\
\hline 40 & 30 & 13,4 & 3,25 & 1,876 & 65,896 & 5,89 & 8,94 \\
\hline 40 & 0 & 15,4 & 3,25 & 2,156 & 65,896 & 0 & 0 \\
\hline 45 & 90 & 11,3 & 3,6 & 1,882 & 89,838 & 14,9 & 16,59 \\
\hline 45 & 70 & 14 & 3,6 & 1,96 & 89,838 & 14,36 & 15,98 \\
\hline 45 & 50 & 15,7 & 3,6 & 2,198 & 89,838 & 11,5 & 11,8 \\
\hline 45 & 30 & 16,5 & 3,6 & 2,31 & 89,838 & 7,2534 & 8,1 \\
\hline 45 & 0 & 17,9 & 3,6 & 2,506 & 89,838 & 0 & 0 \\
\hline
\end{tabular}

The results of this test in Table 1, are outlined in a graphical form so that it can be seen the tendency of the relationship between one variable and the other variables used in this study.

For the $25^{\circ}$ water flow steering angle, all the data are written in Table 1. The relationship between the turbine parameters on a water flow steering angle is plotted. In Fig. 7 it is seen a plotted graph of the relationship between the turbine rotation and the turbine torque.

For the turbine test with a steering angle of $25^{\circ}$, the highest turbine torque is about $2,5 \mathrm{Nm}$, occurs at the water flow rate of $45 \mathrm{~m}^{3} / \mathrm{h}$ and at a maximum turbine braking, as seen in Fig. 7. Furthermore, the highest turbine torque at a water flow rate equal to $40 \mathrm{~m}^{3} / \mathrm{h}$ is about $2,2 \mathrm{Nm}$. Furthermore, the lowest turbine torque occurs at a time when the water flow rate is equal to $40 \mathrm{~m}^{3} / \mathrm{h}$ and at a $45 \mathrm{~m}^{3} / \mathrm{h}$.

In Fig. 8, it could be seen, the relationship between the turbine rotation and the turbine efficiency graph, on a $25^{\circ}$ water flow steering angle. This plotted data is also taken from the experimental data written in Table 1. 


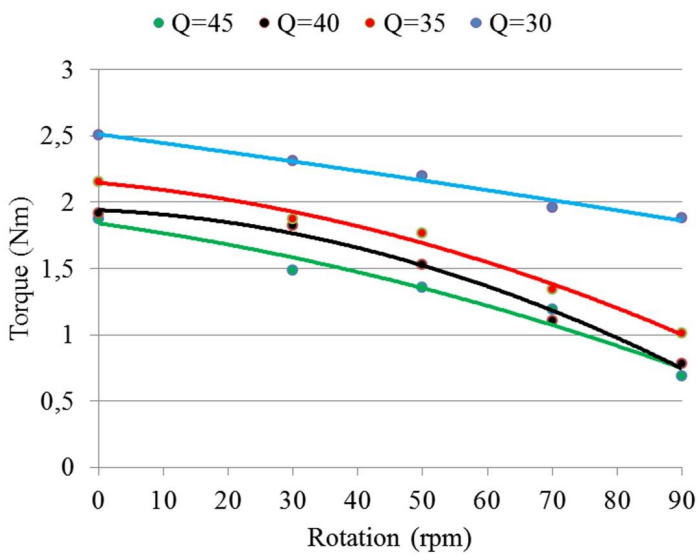

Fig. 7. The relationship between the turbine rotation vs turbine torque at a $25^{\circ}$ flow steering angle

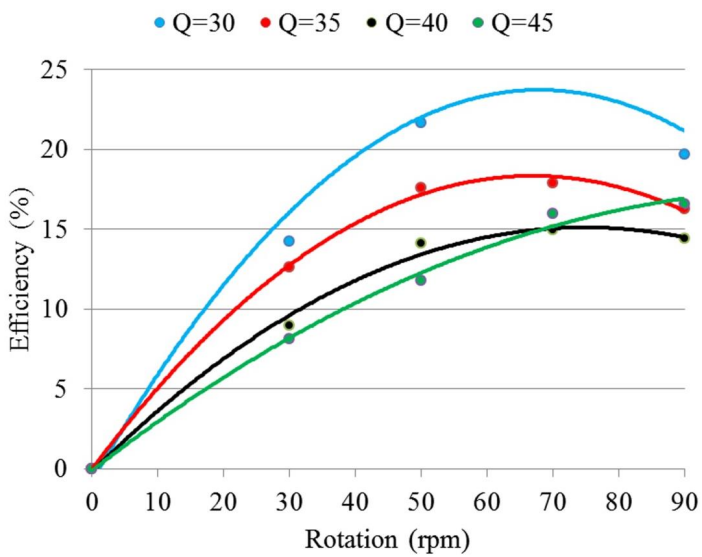

Fig. 8. The relationship between the turbine rotation vs turbine efficiency at a $25^{\circ}$ flow steering angle

From Fig. 8 it is seen that the highest turbine efficiency occurs at a water flow rate of $\mathrm{Q}=30 \mathrm{~m}^{3} / \mathrm{h}$ under a turbine rotation of $\mathrm{n}=60 \mathrm{rpm}$. The turbine efficiency is about $24 \%$. The second highest turbine efficiency occurs at a flow rate of Q is equal to $35 \mathrm{~m}^{3} / \mathrm{h}$ under a $60 \mathrm{rpm}$ turbine rotation. The turbine efficiency is about $18 \%$. However, the lowest turbine efficiency occurs at a flow rate value of $40 \mathrm{~m}^{3} / \mathrm{h}$ and at a flow rate of $45 \mathrm{~m}^{3} / \mathrm{h}$.

Another plotted data for a $25^{\circ}$ water flow steering angle, is the relationship between the turbine rotation and the turbine power produced. This plotting data could be seen in Fig. 9. This data plotted is also taken from Table $\mathbf{1 .}$

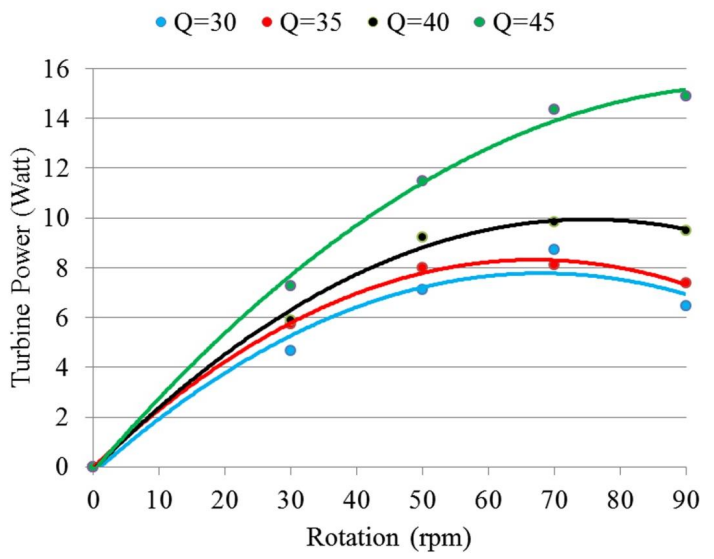

Fig. 9. The relationship between the turbine rotation vs turbine power at a $35^{\circ}$ flow steering angle 
For the highest turbine power produced it can be seen in Fig. 9. The highest turbine power occurred when the water flow rate reaches $45 \mathrm{~m}^{3} / \mathrm{h}$ at an $80 \mathrm{rpm}$ turbine rotation. The maximum turbine power is $15.5 \mathrm{~W}$. The highest turbine power at a water flow rate of $40 \mathrm{~m}^{3} / \mathrm{h}$ is about $10 \mathrm{~W}$ under a $70 \mathrm{rpm}$ turbine rotation. On the other hand, the lowest turbine power occurs at a flow rate of $35 \mathrm{~m}^{3} / \mathrm{h}$ and at a flow rate of $30 \mathrm{~m}^{3} / \mathrm{h}$.

Table 2 shows the laboratory test results for a water flow steering angle $\alpha=35^{\circ}$. The water flow rate variations are $30 \mathrm{~m}^{3} / \mathrm{h}, 35 \mathrm{~m}^{3} / \mathrm{h}, 40 \mathrm{~m}^{3} / \mathrm{h}$ and $45 \mathrm{~m}^{3} / \mathrm{h}$. The turbine rotation variation is $90 \mathrm{rpm}, 70 \mathrm{rpm}, 50 \mathrm{rpm}, 30 \mathrm{rpm}$ and a maximum braking turbine rotation which is equal to $0 \mathrm{rpm}$.

Table 2

Kinetic Turbine Test Results $\left(\alpha=35^{\circ}\right)$

\begin{tabular}{cccccccc}
\hline $\mathbf{Q} \mathbf{~ m}^{\mathbf{3}} \mathbf{h}$ & $\mathbf{n}(\mathbf{r p m})$ & $\Delta \mathbf{F}(\mathbf{N})$ & $\mathbf{V}(\mathbf{m} / \mathbf{s})$ & $\mathbf{T}(\mathbf{N m})$ & Water Power & Turbine Power & $\mathbf{E f f}$ \\
\hline 30 & 90 & 6,4 & 2,6 & 0,896 & 32,8 & 8,44 & 25,7 \\
30 & 70 & 8,4 & 2,6 & 1,176 & 32,8 & 8,62 & 26,26 \\
30 & 50 & 10,1 & 2,6 & 1,414 & 32,8 & 7,4 & 22,56 \\
30 & 30 & 11,4 & 2,6 & 1,596 & 32,8 & 5,1 & 15,28 \\
30 & 0 & 14,2 & 2,6 & 1,988 & 32,8 & 0 & 0 \\
35 & 90 & 8,7 & 2,86 & 1,218 & 45,36 & 11,47 & 25,29 \\
35 & 70 & 11,8 & 2,86 & 1,652 & 45,36 & 12,1 & 26,68 \\
35 & 50 & 13,5 & 2,86 & 1,89 & 45,36 & 9,891 & 21,8 \\
35 & 30 & 16 & 2,86 & 2,24 & 45,36 & 7,03 & 15,5 \\
35 & 0 & 16,1 & 2,86 & 2,254 & 45,36 & 0 & 0 \\
40 & 90 & 10,8 & 3,25 & 1,512 & 65,896 & 14,24 & 21,6 \\
40 & 70 & 13,9 & 3,25 & 1,946 & 65,896 & 14,26 & 21,63 \\
40 & 50 & 15,5 & 3,25 & 2,17 & 65,896 & 11,36 & 17,23 \\
40 & 30 & 16,6 & 3,25 & 2,324 & 65,896 & 7,3 & 11,07 \\
40 & 0 & 19 & 3,25 & 2,66 & 65,896 & 0 & 0
\end{tabular}

The results of this test, in Table 2, are outlined in a graphical form so that it can be seen the tendency of the relationship between one variable and the other variables used in this study.

To facilitate the research data reading as outlined in Table 2, it is necessary to show the relationship between one research parameter and the other research parameters. For water flow steering angle $\alpha=35^{\circ}$, the first graph that is presented in the form of plotted graph is the relationship between the turbine rotation and the turbine torque, as seen in Fig. 10.

For the turbine test with a steering angle of $\alpha=35^{\circ}$, the highest turbine torque is about $3.1 \mathrm{Nm}$, occurs at the water flow rate of $45 \mathrm{~m}^{3} / \mathrm{h}$ and at a maximum turbine braking, as seen in Fig. 10. Furthermore, the highest turbine torque at a water flow rate equal to $40 \mathrm{~m}^{3} / \mathrm{h}$ is about $2.65 \mathrm{Nm}$. Furthermore, the lowest turbine torque occurs at a time when the water flow rate is equal to $40 \mathrm{~m}^{3} / \mathrm{h}$ and at a $45 \mathrm{~m}^{3} / \mathrm{h}$ water flow rate.

Next on Fig. 11, the graph displayed is the relationship between the turbine rotation and the turbine efficiency. The data, for a water flow steering angle $\alpha=35^{\circ}$, was plotted from Table 2 . This graph is necessary to be shown because there is a possibility that the maximum turbine efficiency is not necessarily followed by a high turbine torque. Or even the turbine power produced is the lowest. 


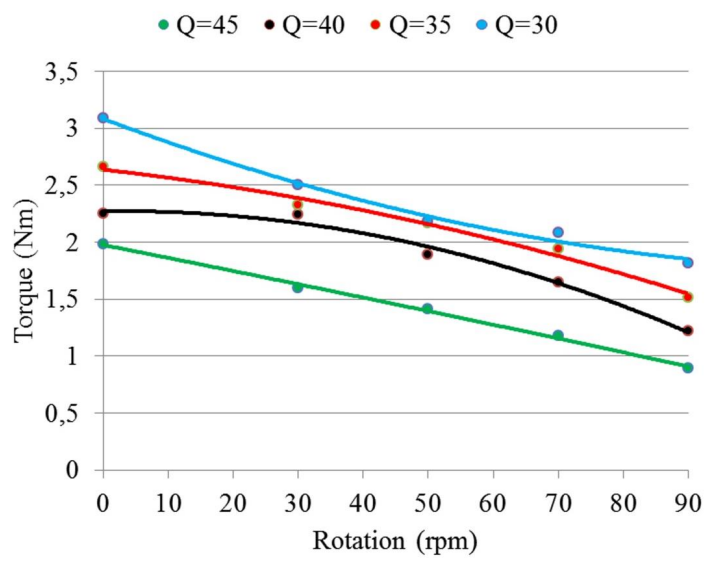

Fig. 10. The relationship between the turbine rotation vs turbine torque at a $35^{\circ}$ flow steering angle

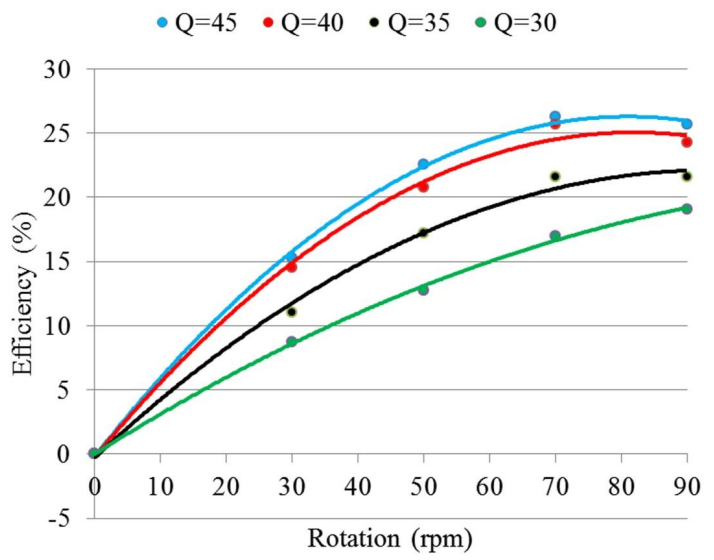

Fig. 11. The relationship between the turbine rotation vs turbine efficiency at a $35^{\circ}$ flow steering angle

From Fig. 11 it is seen that the highest turbine efficiency occurs at a water flow rate of $\mathrm{Q}=30 \mathrm{~m}^{3} / \mathrm{h}$ under a turbine rotation of $\mathrm{n}=60 \mathrm{rpm}$. The efficiency value is about $27 \%$. The second highest turbine efficiency occurs at a flow rate of Q is equal to $35 \mathrm{~m}^{3} / \mathrm{h}$ under a $60 \mathrm{rpm}$ turbine rotation. The turbine efficiency is about $25 \%$. However, the lowest turbine efficiency occurs at a flow rate value of $40 \mathrm{~m}^{3} / \mathrm{h}$ and at a flow rate of $45 \mathrm{~m}^{3} / \mathrm{h}$.

To connect the three turbine performance parameters, it is also necessary to present the relationship between the turbine rotation and the turbine power produced. The relationship between the turbine rotation and turbine power produced is presented in Fig. 12. This graph is a plotted data for a water flow steering angle $\alpha=35^{\circ}$.

For the highest turbine power produced it can be seen in Fig. 12. The highest turbine power occurred when the water flow rate reaches $45 \mathrm{~m}^{3} / \mathrm{h}$ at an $80 \mathrm{rpm}$ turbine rotation. The maximum turbine power is $17.5 \mathrm{~W}$. The highest turbine power at a water flow rate of $40 \mathrm{~m}^{3} / \mathrm{h}$ is about $14.5 \mathrm{~W}$ under a $70 \mathrm{rpm}$ turbine rotation. On the other hand, the lowest turbine power occurs at a flow rate of $35 \mathrm{~m}^{3} / \mathrm{h}$ and at a flow rate of $30 \mathrm{~m}^{3} / \mathrm{h}$.

As can be seen from the research results that the maximum turbine torque occurs at the time of the water flow steering angle position $\alpha=35^{\circ}$ and at a maximum water flow rate $Q=45 \mathrm{~m}^{3} / \mathrm{h}$. In this condition the turbine efficiency is the lowest. While for the maximum turbine efficiency, which is about $27 \%$, the water flow rate is about $30 \mathrm{~m}^{3} / \mathrm{h}$ at $60 \mathrm{rpm}$ turbine rotation and a water flow steering angle $\alpha=35^{\circ}$. As a consideration, the water flow rate used is the Q maximum. So if there is a water flow rate setting for reasons of optimizing water management, the optimum water flow 
steering condition $\alpha=35^{\circ}$ needs to be considered. Because the turbine design will affect the water flow parameters involved in this prime moving design.

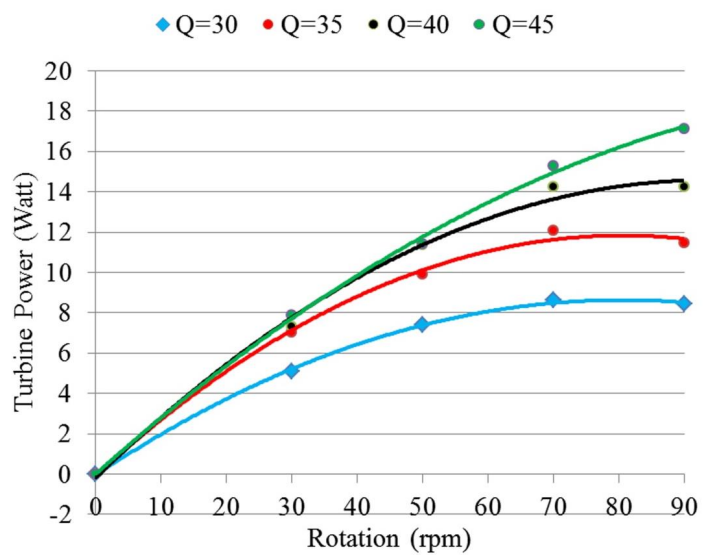

Fig. 12. The relationship between the turbine rotation vs turbine power at a $35^{\circ}$ flow steering angle

For the largest selection of turbine rotation, water flow steering angle value $\alpha=35^{\circ}$ could be taken. This parameter is chosen, if the reason is to get a large P power of $17.5 \mathrm{~W}$ in a water flow rate $\mathrm{Q}=45 \mathrm{~m}^{3} / \mathrm{h}$, while the turbine efficiency is about $16.5 \%$. Again the high water flow rate must be taken account related to the water management system.

For the maximum torque selection, the water flow steering angle $\alpha=35^{\circ}$ and the water flow rate of $\mathrm{Q}=45 \mathrm{~m}^{3} / \mathrm{h}$, where the turbine torque value is about $3 \mathrm{Nm}$. Again, it is at the maximum water flow rate that would affect the water management system.

\section{Conclusions}

Based on the results on the hydrokinetic turbine for low water flow rate channels research, which vary the turbine torque, water flow steering angle and water flow rate, it can be concluded that:

1. The water flow steering angle greatly affects the kinetic turbine performance. The kinetic turbine performance is the turbine torque, the turbine efficiency and the turbine power produced.

2. The best flow steering angle, in this case, is the water flow steering angle with $\alpha=35^{\circ}$.

Although the best water flow steering angle is $35^{\circ}$, there are still many considerations of the turbine design parameters. Because there are a lot more factors that influence the turbine design, one of them is the environmental factors.

\section{References}

[1] Indonesia Energy Outlook 2017. Agency for the Assessment and Application of Technology.

[2] Monintja, N. C. V., Soenoko, R., Wahyudi, S., Irawan, Y. S. (2014). The Influence of Flow Steering Angle on the Performance of a Cup-Bladed Kinetic Turbine. International Journal of Applied Engineering Research, 9 (20), 7481-7489.

[3] Rispiningtati (2014). Rule curve of Selorejo hydro power to have maximal electrical energy. International Journal of Applied Engineering Research, 9 (10), 1477-1481.

[4] Gaden, D. L. F., Bibeau, E. L. Increasing Power Density Of Kinetic Turbines for Cost-effective Distributed Power Generation. Departmen Mechanical and Manufacturing Engineering, University of Manitoba, Canada. Available at: https://home.cc.umanitoba.ca/ bibeauel/research/papers/2006_Gaden_ powergen.pdf

[5] Soenoko, R., Rispiningtati, Sutikno, D. (2011). Prototype of a Twin Kinetic Turbine Performance as a Rural Electrical Power Generation. Journal of Basic and Applied Scientific Research, 1 (10), 1686-1690

[6] Williamson, S. J., Stark, B. H., Booker, J. D. (2013). Performance of a low-head pico-hydro Turgo turbine. Applied Energy, 102, 1114-1126. doi: https://doi.org/10.1016/j.apenergy.2012.06.029 
[7] Kailash, G., Eldho, T. I., Prabhu, S. V. (2012). Performance Study of Modified Savonius Water Turbine with Two Deflector Plates. International Journal of Rotating Machinery, 2012, 1-12. doi: https:// doi.org/10.1155/2012/679247

[8] Tian, W., Mao, Z., Ding, H. (2018). Design, test and numerical simulation of a low-speed horizontal axis hydrokinetic turbine. International Journal of Naval Architecture and Ocean Engineering, 10 (6), 782-793. doi: https://doi.org/10.1016/j.ijnaoe.2017.10.006

[9] Lopes, J. J. A., Vaz, J. R. P., Mesquita, A. L. A., Mesquita, A. L. A., Blanco, C. J. C. (2015). An Approach for the Dynamic Behavior of Hydrokinetic Turbines. Energy Procedia, 75, 271-276. doi: https:// doi.org/10.1016/j.egypro.2015.07.334

[10] Jaini, Kaprawi, Santoso, D. (2015). Darrieus Water Turbine Performance Configuration of Blade. Journal of Mechanical Science and Engineering, 2 (1), 7-11.

[11] Sukmawaty, S., Firdaus, N., Putra, G. M. D., Ajeng, S. D. (2018). Effect of Blade number and Directional Plate Angle on Kinetic Turbine Performances. International Journal of Mechanical Engineering and Technology (IJMET), 9 (13), 395-402.

[12] Hantoro, R., Septyaningrum, E. (2018). Novel Design of a Vertical Axis Hydrokinetic Turbine Straight-Blade Cascaded (VAHT-SBC): Experimental and Numerical Simulation. Journal of Engineering and Technological Sciences, 50 (1), 73-86. doi: http://doi.org/10.5614\%2Fj.eng.technol.sci.2018.50.1.5

[13] Zanforlin, S., Burchi, F., Bitossi, N. (2016). Hydrodynamic Interactions Between Three Closely-spaced Vertical Axis Tidal Turbines. Energy Procedia, 101, 520-527. doi: https://doi.org/10.1016/j.egypro.2016.11.066

[14] Góralczyk, A., Adamkowski, A. (2018). Model of a Ducted Axial-Flow Hydrokinetic Turbine Results of Experimental and Numerical Examination. Polish Maritime Research, 25 (3), 113-122. doi: https:// doi.org/10.2478/pomr-2018-0102

[15] Anyi, M., \& Kirke, B. (2010). Evaluation of small axial flow hydrokinetic turbines for remote communities. Energy for Sustainable Development, 14 (2), 110-116. doi: https://doi.org/10.1016/ j.esd.2010.02.003

[16] Boedi, S. D., Soenoko, R., Wahyudi, S., Choiron, M. A. (2015). An Outer Movable Blade Vertical Shaft Kinetic Turbine Performance. International Journal of Applied Engineering Research, 10 (4), 8565-8573.

[17] Soenoko, R., Setyarini, P. H., Gapsari, F. (2018). Bowl Bladed Hydro Kinetic Turbine Performance. ARPN Journal of Engineering and Applied Sciences, 13 (20), 8242-8250.

[18] Lempoy, K. A., Soenoko, R., Wahyudi, S., Choiron, M. A. (2019). Movable blade vertical shaft kinetic turbine visual observation. Eastern-European Journal of Enterprise Technologies, 2 (8 (98)), 23-30. doi: https://doi.org/10.15587/1729-4061.2019.163418 